\title{
A Review of the Relationship between Ownership Structure and Economic Performance Criteria in Companies Listed on Tehran Stock Exchange
}

\author{
Ali Yaghoobi ${ }^{1} \&$ Ehsan khansalar ${ }^{2}$ \\ ${ }^{1}$ Department of Accounting, Qaenat Branch, Islamic Azad University, Qaenat, Iran \\ ${ }^{2}$ Departement of Accounting, Finance and Informatics, Kingston University, London, UK \\ Correspondence: Ali Yaghoobi, Department of Accounting, Qaenat Branch, Islamic Azad University, Qaenat, \\ Iran. E-mail: aliyaghoobi120@gmail.com
}

Received: March 12, 2016

Accepted: May 3, 2016

Online Published: May 25, 2016

doi:10.5539/ijef.v8n6p89

URL: http://dx.doi.org/10.5539/ijef.v8n6p89

\begin{abstract}
The aim of this study is to investigate the relationship between ownership structure and economic performance criteria of companies listed on Tehran Stock Exchange. This study is a descriptive- applied research that reviews the cross-sectional data relating to 114 listed companies between 1387-1393. Multivariate regression is used to analyze the effect of each of these factors on economic performance.

The results show that from three applied independent variables in the regression model, there is a significant relationship in a 95\% confidence level between Institutional ownership and property management and economic value added and modified economic value added but there is not any relationship between ownership concentration variable and economic performance criteria. The obtained determination coefficient for the above relationship shows that the independent variables explain only part of the economic performance, and investors need to consider other factors as well to evaluate the economic performance of the company.
\end{abstract}

Keywords: institutional ownership, real ownership, ownership concentration, economic performance

\section{Introduction}

The most important feature in a joint stock company is the segregation of ownership from the management. In the past thirty years many cases of conflict of interest between different groups and how the companies deal with these conflicts have been raised by theeconomists. .

These cases are generally suggested under the title of "agency theory" in management accounting.

Jensen and Meckling define an agency relationship as a contract under which one or more persons (the principal(s)) engage another person (the agent) to perform some service on their behalf which involves delegating some decision making authority to the agent.

Shareholders and the level of ownership concentration, are two principle aspects of firms ownership structure. The separation of ownership and control raises a discussion about the relationship between stockholders and the managers. How the managers do their best as the financial theories suggest to raise the stockholders interests?

The main users of financial information are shareholders. In a division, shareholders may be divided into natural and legal persons which in financial literature are known to "institutional investors".

Natural investers mainly rely on public available information as the published financial statements. Among them the institutional investors, including investment institutions and other businesses, with regard to the ownership of a large part of companies' shares enjoyed considerable influence and access to the various information about the future prospects and the company's plans or even the future contracts.

On the one hand, these investors are considered professional stockholders and in their decision about the investment view all aspects of the above mentioned firms.

Institutional investors review one of the strong corporate governance mechanisms that can control the management of the company, Because they can both have a significant influence on company management, and also they can put the management interests with the interests of shareholders in the same line (Ali Ebrahimi Kordlar, 1392). 
In terms of concentration the ownership of a company may also be spread ownership (a large number of small shareholders) or concentrated ownership (very few major shareholders). When ownership is in the hands of major shareholders, control system will be centralized but in the case of distributed ownership, control system will be decentralized (Gunnar \& Corsican, 2003).

\subsection{Statement of the Problem}

Until the 1980s agency conflict between shareholders and managers was the main theme in ownership structure literature. It was generally accepted that the ownership concentration reduces the agency problems and this in itself improves the firm performance (Jensen \& Meckling, 1976).

The researchers suggestthat increasing ownership concentration causes the big investors enter the firm ownership structure and they posses enough motivation and power to control the managers and their control causes the managers to take long-term steps towards the firm goals (Schiffer \& Vishny, 2006).

Enron and WorldCom scandals in 2001 led to much researchesin terms of ownership structure. Many researchers find that an appropriate ownership structure has a positive effect on firm performance and its market value (Gompers et al., 2003).

The ownership structure involves a set of relationships between shareholders, directors, auditors and other beneficiaries which warrants the establishment of a control system in order to protect rights of minority shareholders and proper implementation of the decisions of the Assembly and to prevent possible misuse.

Maug (1998) in his research concluded that the use of institutional investors of their ability for supervising on management and company performance depends on rate of their investment. Whatever the rate of institutional ownership increases, supervision on management improves, and it is a direct relationship which in consequence led to the improvement of firm performance (economic performance) and its market value.

Firms believe that an appropriate ownership structure facilitates effective control and management of business units and empowers optimal efficiency for all stakeholders.

The conducted researches in the field of ownership structure are based on agency theory and the issue of conflict of interests. the conflict of interests occurs whenever there is a controversy between the interests of the managers and those of stockholders

Agency theory suggests that the firms that have a better corporate ownership structure also have a better performance and higher values because of their lower agency costs. Agency theory also acknowledges that ownership concentration led to better firm control and management since the big stockholders possess higher motivation and ability for supervising the management and increasing firm efficiency (Justin et al., 2009).

Also it is expected that when in a firm one person handles the CEO and Chairman of the Board this structure allows to the CEO to manipulate the information which is available to the board members so this impedes an effective earning management control (Jensen, 1993).

\section{Research Background}

Zhou and Wang (1999) in a research reviews the relationship between ownership structure and corporate govenance in China exchange. They concluded that institutional investors have a positive impact on firms profitability.

Gedajlovic and Shapiro (2002) review the relationship between ownership concentration and financial operation in Japanese firms. Their results show that there is a positive and signficant relationship between these two variables. Joe (2008) in a research show that the reduction of ownership concentration results in a reduction in profitability in Corean firms.

Mueller and Spitz (2006) focus on the relationship between managerial ownership and small and medium-sized private enterprises operation in Germany Their findings show that performance, measured by survey-based profit information, is increasing in managerial ownership by up to around 40 percent.

Kapopoulos and Lazaretou (2007) assess the impact of the structure of ownership on corporate performance, measured by profitability, using data for 175 Greek listed firms. their research results show that there is a positive and significant relationship between more concentrated ownership structure and firm profitability.

Wang et al. (2009) review the effect of ownership structure features on Chinese firms operations. They note two approches of ownership structure in their research. First they review the impact of each one of ownership structure characteristics on firns perfarmance then thy review the impact of all ownership structure characteristics on firms performances. They concluded that the firms that have the better ownership structure 
mechanism also have a better performance and valuation .Also there is a positive and significant relationship between ownership concentration, institutional investors, state ownership and firm performance and its market value.

Nthoesane (2012) suggested that conomic value added (EVA) is regarded as the true measure of economic value and has since been utilised as a tool for executives' compensation. Inherent to compensating executives on EVA, is the underlying assumption that executives were selected on their ability to create value attributes and competency measures are some of the measures that can predict performance. Based on this, conceptualises thatattributes and competencies that are linked to EVA be identified in order to develop a competency measure that is based on EVA. However he believes that there is not any significant relationship between conomic value added (EVA) and executives compensations so the stockholders do not consider it as a suitable measure for performance.

Machuga, Pfeiffer, and Verma (2002) in their economic value added research premised that economic value added(EVA)and future earnings and financial analysis in association with predicting earning per share (EPS) are useful. They concluded that Eva can be useful for predicting EPS in profitable firms and there are extra information for explaining earning per share variables in the future and also cash flow and Accrual component of earnings.

Garcia et al. (2011) review the relationship between ownership structure and the accuracy of their earnings forecasts. The ownership structure examined in this study includes the concentration of ownership, bank ownership and external ownership. They use the absolute value of the difference between the real earning and predicted earning divided by actual profit. Their findings indicates a significant relation between bank ownership and Earning Forecast Accuracy (EFA), with ownership concentration and managerial ownership having no significant impact on EFA.

Vaidehi et al. (2012) review the relationtip between local investors and ownership structure they raise this issue that whether the local instititutional investments results in controlled operation improvement and finally leading to profitability or not? Thir results indicates that the existance of institutional investors result in improvement of control activities and reduction of executives compensarion and finally it leads to more managers turnover.

Noravesh and EbrahimiKordlar (1384), in their study examine the relationship between Shareholders and information asymmetry and usefulness of accounting standards of their performance. The results of their study show that companies that have greater institutional ownership in comparison to the firms that have less institutional ownership have higher stock prices and future earning forecasts.

Namazi and Kirmani (1387) examine the impact of ownership structure on the performance of companies listed on Tehran Stock Exchange. Their statistical sample consists of 66 companies during the years 1382 to 1386 . The results of their research show that there is a significant relationship between of firms ownership structure and their performance.

Hassas Yeganeh et al. (1384) review the relationship between institutional investors and firm value, they use Multiple linear regression to test their research hypothesis. Their results show that there is a positive and significant relationship between institutional investors and firm value.

Ahmad Pur and Ahmadi (1387) examine both the qualitative characteristics of information with each other as a criterion for assessing the quality of corporate profits .in their study they use both the relevance and reliability of information for evaluating the quality of corporate profits and the results indicate that earnings response coefficient (ERC) and profit explanatory power (R2) of the companies which possess high relevant and reliable portfolio significantly are higher than the portfolio of the companies with low relevance and reliability.

Khodadadi and Taker (1390) examine the impact of the ownership structure features including the concentration of ownership, institutional investors, government ownership, managerial ownership, duality Director and the percentage of outside directors on the board on the financial performance and value of companies have tested. In this context, data from 80 firms listed in the Tehran Stock Exchange in the period from 1384 to 1387 were used. The results show that the concentration of ownership and state ownership has a positive correlation with the performance and value of companies that are significant. Major institutional investment with the value of the company has a positive relationship with firm performance negatively. Duality Director of the Company has significant negative correlation was not significant relationship with firm performance. The structure of the ownership structure of the company and its performance has been positive and significant relationship.

Moghaddam and Kazemipour (1391), review the effect of private ownership on the economic value added and the rate of return on assets (ROA) in companies listed on Tehran Stock Exchange. 
Since privatization has been highly regarded in recent years, thus a review of the rate of the success of this privatizations is very critical.

This research has been conducted during 1383 to 1386 and its statistical population consists of all companies listed on the Tehran Stock Exchange. The results suggest that there is a direct and significant relationship between the percentage of private sector ownership and return on assets and significant economic value added.

Also 14 percent value-added economic changes and 7\% rate of return on assets is determinable by the percentage of private property. In addition, there is a significant relationship between the rate of return on assets and the economic value added.

Jalili et al. (1392) assess the financial value indicators potency and profitability in explaining stock returns of companies listed on Tehran Stock Exchange.

The results show that among the independent variables there is a significant relationship between net income and stock returns. Other independent variables as market added value, cash added value, return on assets and return on equity, have a significant relationship with stock returns, but this relationship is not as much as economic value added.

Kashanipoor et al. (1393), in a study examine the relationship between the board structure and firm ownership structure which are voluntarily disclosed by listed companies in Tehran Stock Exchange. The statistical sample of their research includes 148 companies in 1391 and the statistical method used for testing statistical hypothesis, includes multivariate regression. The findings show that there is a significant and positive relationship between the "rate of non-executive members" and "corporate ownership" and voluntarily disclosure. However there is not any significant relationship between "board size", "managerial ownership", "institutional ownership" and voluntary disclosure.

Mohammad Reza Ola et al. (1393), in study examine the relationship between corporate governance and economic value added in Tehran Stock Exchange the results of this study show that amongst five elements of corporate governance (including the percentage of institutional ownership, major shareholders ownership percentage, the ownership percentage of controlling shareholders, the separation of the roles of CEO and Chairman of the Board anduncommitted board members) only institutional investors ownership percentage variable has a positive and significant effect on economic value added. In addition, the causal relationship of this variables with economic value is confirmed based on Granger causality test. Iran Khodrocompany, Mines and Metals investment, and Saipa company respectively, possess the highest impact of corporate governance on their economic value added.

\section{Research Hypotheses}

First hypothesis: there is a significant relationship between concentration of ownership and economic value added (Eva).

The second hypothesis: there is a significant relationship between institutional ownership and economic value added (Eva).

The third hypothesis: there is a significant relationship between managerial ownership and economic value added (Eva).

The fourth hypothesis: there is a significant relationship between the concentration of ownership and modified economic value added (REva).

Fifth hypothesis: there is a significant relationship between institutional ownership and modified economic value added (REva).

Sixth hypothesis: there is a significant relationship between managerial ownership and modified economic value added (REva).

To examine the relationship between ownership structure and economic performance criteria, regression models are used to test the following hypotheses:

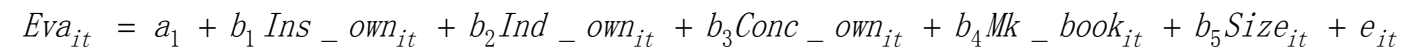

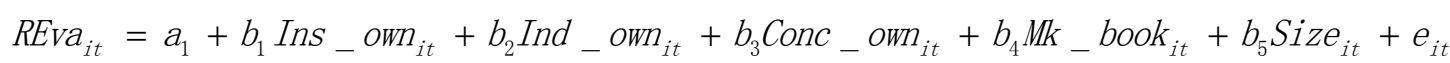

Where,

EVA: Economic Value Added 
NOPAT: net operating profit after tax at the end of period $t$

WACC: weighted average cost of capital rate

CAPITAL t-1: Total capital to book value at the beginning of period $t$ (end of $t-1$ )

Refined Economic Value Added

$$
R E V A_{i t}=N O P A T_{i t}-W C_{i t}\left(M C A P I T A L_{i t-1}\right)
$$

Where,

NOPAT $=$ net operating profit after tax in the period $t$;

WACC $=$ weighted average cost of capital;

MCAPITALit-1 $=$ firm market value at the beginning of period $\mathrm{t}($ end of period $\mathrm{t}-1)+($ Number of shares of the firm stock market price in the first period $t$

$=$ MVit=MCAPITALit;

Interest-free current liabilities - total market value of debt

\section{Independent variables}

FEet: the difference between net real profit and predicted net profit per share divided by the absolute value of per share anticipated net profit.

Ins_ownit: percentage of institutional ownership common stocks in the Company for the period t.

Ind_ownit: the percent of common stock general ownership of in the company $i$ for period $t$.

Conc_ownit: the percent ofthe concentration of ownership of common stocks in the Company for the period t.

\section{Control variables}

MV / BV: it is calculated by dividing the market value of equity to book value of each company.

Sizeit: size of the company which is calculated based on the natural logarithm of the assets of each company.

\section{Population and Sample}

The statistical population in this study includes all the firms listed in Tehran Stock Exchange. The reason for including firms listed on Stock Exchange is the greater access to their financial information,

In addition, because of Tehran Stock Exchange regulations and standards, the financial information reported by these companies is more homogeneous. In this study, all Available data are used to select a sample.

First, all companies are included in the sampling, then from them, the companies that do not meet any of the following requirements, are removed from this study.

1) firm fiscal year ended Esphand each year.

2) during the period of investigation the fiscal year of the firm has not been changed.

3) During the period of investigation the firm is actively involved in the exchange.

4) the firm information is available to extract data.

5) the firm shall be an Investment Co., not a financial broker.

The research period covers 1387-1393.

In view of the above circumstances from 420 companies listed on the exchange, 114 companies are selected as our sample size.

\section{Research Results Analysis}

In order to better understand the research population and to learn more about the variables, before the analysis of statistical data the data should be described. Statistical description of data, is a step towards the recognition of their patternand it is considered as a basis for determining the relationships between the variables which are used in the research.

Descriptive statistics, includes mean, median, standard deviation, maximum and minimum for all the studied variables in this research which are shown Table 1. 
Table 1. Descriptive statistics

\begin{tabular}{cccccl}
\hline Variance & Standard deviation & mean & maximum & Minimum & Description \\
\hline 3.332 & 1.82524 & 18.2667 & 20.89 & 5.14 & economic value added logarithm \\
3.332 & 1.62545 & 18.1601 & 20.78 & 5.03 & Logarithm of refined economic value added \\
489.301 & 22.12014 & 19.887 & 0.2192 & 0.02 & Institutional investors \\
0.046 & 0.21372 & 0.697 & 1 & 0.0001 & Real ownership \\
3.059 & 1.74893 & 0.8207 & 2.220 & 0.0001 & Ownership concentration \\
0.031 & 0.17522 & 0.612 & 0.97 & 0.1 & Market value to book value \\
2.165 & 1.47135 & 13.3093 & 18.44 & 10.09 & Company size (a ratio of logarithm of the obtained assets) \\
\hline
\end{tabular}

Table 1 indicates the descriptive statistics which includes mean, standard deviation, maximum and minimum for all variables in this study.

Firms economic value added (EVA) and refined economic value added mean between firms are 18.2667 and 18.1601. At the same time the mentioned data standard deviations are 1.825 and 1.625.

Also the natural and legal shareholders by relatively the same ratio, assumed the ownership of the stock market. The existence of the legal stockholders in one hand stabilize the company but on the other hand if a suitable management is not applied by the institutional stockholders they can exert a negative effect .

Also in the listed firms in exchange the ownership concentration enjoys a high figure. this variable mean is 82 for the listed firms which indicates that the major shareholders, play an important role in the market. At the same time the high volume of these shareholders in the Company ownership means that small shareholders have an insignificant role in managing companies and this case is in conflict with new approaches to the stock market which suggest that the firms should have a high versatility whether in ownership or the Board of Directors, so that the rights of all owners and the interests of society as a whole be considered.

Table 2. Pearson correlation coefficient

\begin{tabular}{|c|c|c|c|c|c|c|c|c|}
\hline \multirow{2}{*}{$\begin{array}{c}\text { Firm size } \\
-0.031\end{array}$} & \multirow{2}{*}{$\begin{array}{c}\begin{array}{c}\text { Market value } \\
\text { to book value }\end{array} \\
-0.008\end{array}$} & \multirow{2}{*}{$\begin{array}{c}\text { Ownership } \\
\text { concentration }\end{array}$} & \multirow{2}{*}{$\begin{array}{c}\begin{array}{c}\text { Natural } \\
\text { investors }\end{array} \\
0.002\end{array}$} & \multirow{2}{*}{$\begin{array}{c}\begin{array}{c}\text { Institutional } \\
\text { investors }\end{array} \\
-0.04\end{array}$} & \multirow{2}{*}{$\begin{array}{c}\begin{array}{c}\text { Logarithm of } \\
\text { refined economic } \\
\text { value added }\end{array} \\
1.000\end{array}$} & \multirow{2}{*}{$\begin{array}{c}\begin{array}{c}\text { economic } \\
\text { value added } \\
\text { logarithm }\end{array} \\
1\end{array}$} & \multicolumn{2}{|c|}{ variable names } \\
\hline & & & & & & & Dort & economic \\
\hline 0.424 & 0.041 & 061 & 0056 & 0002 & 0 & 0 & Sionificance level & added \\
\hline 684 & 684 & 684 & 684 & 684 & 684 & 684 & numbers & logarithm \\
\hline-0.031 & 0.008 & -0.019 & 0.002 & -0.04 & 1 & 1.000 & Pearson correlation & Logarithm of \\
\hline 0.023 & 0.039 & 0.613 & 0.975 & 0.001 & 0 & 0 & Significance level & refined economic \\
\hline 684 & 684 & 684 & 684 & 684 & 684 & 684 & numbers & value added \\
\hline-0.047 & -0.036 & -0.008 & 0.039 & 1 & -0.04 & -0.04 & Pearson correlation & \\
\hline 0.216 & 0.048 & 0.032 & 0.012 & 0 & 0.301 & 0.002 & Significance level & \\
\hline 684 & 684 & 684 & 684 & 684 & 684 & 684 & numbers & \\
\hline-0.028 & 0.056 & -0.027 & 1 & 0.039 & 0.002 & 0.002 & Pearson correlation & \\
\hline 0.063 & 0.042 & 0.008 & 0 & 0.012 & 0.007 & 0.0026 & Significance level & Real ownership \\
\hline 684 & 684 & 684 & 684 & 684 & 684 & 684 & numbers & \\
\hline 0.008 & -0.005 & 1 & -0.027 & -0.008 & -0.019 & -0.02 & Pearson correlation & \\
\hline 0.042 & 0.09 & 0 & 0.008 & 0.003 & 0.013 & 0.01 & Significance level & \\
\hline 684 & 684 & 684 & 684 & 684 & 684 & 684 & numbers & \\
\hline 0.123 & 1 & -0.005 & -0.056 & -0.036 & -0.008 & -0.008 & Pearson correlation & \\
\hline 0.001 & 0 & 0.09 & 0.042 & 0.048 & 0.039 & 0.041 & Significance level & \\
\hline 684 & 684 & 684 & 684 & 684 & 684 & 684 & numbers & \\
\hline 1 & 0.123 & 0.008 & -0.028 & -0.047 & -0.031 & -0.031 & Pearson correlation & \\
\hline 0 & 0.0001 & 0.042 & 0.063 & 0.016 & 0.023 & 0.024 & Significance level & Firm size \\
\hline 684 & 684 & 684 & 684 & 684 & 684 & 684 & numbers & \\
\hline
\end{tabular}

Table 2 shows the results of Pearson correlation analysis for variables. As presented in the table there is a significant correlation between the behavior of economic value added (EVA) and refined economic value added (REVA) and institutional shareholders, natural ownership and ownership concentration. 
Similarly, there is a positive relationship between firm size and economic value-added and refined economic value added. This variable is used in many empirical accounting studies as a control variable. Zimmerman research (1983) is a starting point for using this variable as a controi variable.

In fact, according to the size based theory of Zimmerman, the political costs of the firm increases. Thismakes them more conservative so they do their best to transfer the profits to coming years.

However, the results suggest that the larger the company, the performance will be better. The reason lies in Zimmerman size theory. In fact, he believes that a double increase in the profits of a big company such as Axon is far more considered than a double increase in profits of a small company like Sybron.

This is also true in Iran. For example, the government does its best to support its automotive industry, and the same support of General Motors is provided by the United States in its recent financial crisis.

Because bankruptcy or financial weakness of these companies can have an irreparable effects on every country's economy, such as a rise in unemployment rate and falling economic growth rate. For example, auto companies in Iran annually employ more than 500 thousand people directly and besides a lot of more people are employed in automotive-related industries. So these companies benefit from more state and social supports.

\subsection{Hypothesis Testing}

In order to determine the variables and their use in performing statistical analysis, Theresearches conducted by Garcia and Sanchez (2013) and Muhammadi and Namazi (1388) are used as references. So for the purposes of this study three hypotheses will be tested as follows:

The result Table 3 first to third research hypothesis regression.

Table 3. The regression results of first to third research hypothesis

\begin{tabular}{|c|c|c|c|c|c|}
\hline Significance level & $\mathrm{T}$ statistics & Standard deviation & coefficients & variables & theories \\
\hline 0.165 & -1.0148 & 0.4198 & -0.4260 & Ownership concentration & \multirow{4}{*}{$\begin{array}{l}\text { The first } \\
\text { hypothesis }\end{array}$} \\
\hline 0.003 & -2.4853 & 0.027 & -0.0671 & Market value to book value & \\
\hline 0.928 & 0.0911 & 0.5032 & 0.0458 & Firm size & \\
\hline 0.000 & 7.5732 & 0.4049 & 3.0664 & Constant coefficient & \\
\hline 0.001 & 1.0148 & 1.3992 & 1.4199 & Institutional ownership & \multirow{4}{*}{$\begin{array}{l}\text { The second } \\
\text { hypothesis }\end{array}$} \\
\hline 0.003 & -2.4853 & 0.027 & -0.0671 & Market value to book value & \\
\hline 0.928 & 0.0911 & 0.5032 & 0.0458 & Firm size & \\
\hline 0.000 & 4.7064 & 0.561 & 2.6405 & Constant coefficient & \\
\hline 0.001 & -0.157 & 426816 & 67069.6 & Managerial ownership & \multirow{4}{*}{$\begin{array}{l}\text { Third } \\
\text { hypotheses }\end{array}$} \\
\hline 0.000 & 6.825 & 27442.04 & 187296.1 & Market value to book value & \\
\hline 0.627 & -0.486 & 511676.8 & 248796.9 & Firm size & \\
\hline 0.000 & -6.171 & 411718.1 & 2540770 & Constant coefficient & \\
\hline
\end{tabular}

\subsubsection{The First Hypothesis Review}

First hypothesis: there is a significant relationship between concentration of ownership and economic value added (Eva).

Test results show that in a significant 95 percent level, the probable rate of its significance $\mathrm{H}_{0}: \rho=0$ is equal to 0.165 , which is larger than 05.0. So $\mathrm{H}_{0}$ hypothesis is accepted. So in a 95 percent significance level, there is not a significant relationship between ownership concentration and economic added value. So the first hypotheses is not approved in a 95 percent significance level.

\subsubsection{The Second Hypothesis Review}

The second hypothesis: there is a significant relationship between institutional ownership and economic value added (Eva).

Test results show that in a significant 95 percent level, the probable rate of its significance $\mathrm{H}_{0}: \rho=0$ is equal to .0006 , which is smaller than 05.0 . So $\mathrm{H}_{0}$ hypothesis is rejected. So in a 95 percent significance level, there is a significant relationship between institutional ownership and economic added value. So the second hypotheses is approved in a 95 percent significance level. 


\subsubsection{Third Hypotheses Review}

The third hypothesis: there is a significant relationship between managerial ownership and economic value added (Eva).

Test results show that in a significant 95 percent level, the probable rate of its significance $\mathrm{H}_{0}$ : $\rho=0$ is equal to 0.005 , which is smaller than 05.0. So $\mathrm{H}_{0}$ hypothesis is rejected. So in a 95 percent significance level, there is a significant relationship between managerial ownership and economic added value. So the third hypotheses is approved in a 95 percent significance level.

The result Table 4 fourth to sixth research hypothesis regression.

Table 4. The regression results of fourth to sixth research hypothesis

\begin{tabular}{cccll}
\hline Significance level & T statistics & Standard deviation & coefficients & variables \\
\hline 0.175 & 0.157 & 1422720 & 223565.3 & Ownership concentration \\
0.000 & 6.825 & 27442.04 & 187296.1 & Market value to book value \\
0.627 & -0.486 & 511676.8 & 248796.9 & Firm size \\
0.000 & -4.571 & 570474 & 2607939 & Constant coefficient \\
0.008 & -1.022203 & 0.207358 & -0.211962 & Institutional ownership \\
0.308 & -1.45250 & 0.5893919 & -0.615986 & Market value to book value \\
0.003 & 0.073047 & 56.43322 & 4.12226 & Firm size \\
0.025 & 2.421273 & 13.58157 & 32.88469 & Constant coefficient \\
0.005 & 0.365106 & 0.01573 & 62055.6 & Managerial ownership \\
0.020 & 0.79109 & 0.107479 & 0.085025 & Market value to book value \\
0.005 & 0.365106 & 0.01573 & 0.005743 & Firm size \\
0.00 & 10.40721 & 1.575648 & 16.3981 & Constant coefficient \\
\hline
\end{tabular}

\subsubsection{Forth Hypothesis Review}

The fourth hypothesis: there is a significant relationship between the the ownership concentration and refined economic value added (REva).

Test results show that in a significant 95 percent level, the probable rate of its significance $\mathrm{H}_{0}: \rho=0$ is equal to.01752, which is greaterr than 05.0. $\mathrm{So}_{0}$ hypothesis is accepted. So in a 95 percent significance evel there is not a significant relationship between ownership concentration rate and refined economic added value. So the fourth hypotheses is approved in a 95 percent significance level.

\subsubsection{Fifth Hypotheses Review}

Fifth hypothesis: there is a significant relationship between institutional ownership and refined economic value adjusted (REva).

Test results show that in a significant 95 percent level, the probable rate of its significance $\mathrm{H}_{0}: \rho=0$ is equal to 0083, which is smaller than 05.0. So $\mathrm{H}_{0}$ hypothesis is rejected. So in a 95 percent significance level, there is a significant relationship between institutional ownership and refined economic added value. So the fifth hypotheses is approved in a 95 percent significance level.

\subsubsection{Sixth Hypotheses Review}

Sixth hypothesis: there is a significant relationship between managerial ownership and refined economic value adjusted (REva).

Test results show that in a significant 95 percent level, the probable rate of its significance $\mathrm{H}_{0}: \rho=0$ is equal to 0.005 , which is smaller than 05.0. So $\mathrm{H}_{0}$ hypothesis is rejected. So in a 95 percent significance level, there is a significant relationship between managerial ownership and economic added value. So the fifth hypotheses is approved in a 95 percent significance level.

\subsection{Results Analysis}

Ownership structure elements include, the ownership percentage of institutional investors, major stakeholders ownership percent and managerial ownership. According to the regression results we can say that, among the above elements of ownership structure, institutional and managerial ownership percent variable have significant and positive effects on economic value added and refined economic value added. 
And probably it is due to this fact that institutional stockholders as one of the external factors in ownership structure system play an important role in reducing agency costs and agency costs have reverse effect on firm value.

In fact, the companies that have experienced greater agency problems, should show a greater willingness to use the performance appraisal system. Also, the large shareholders have their own interests that are sometimes not compatible with the interests of other small stakeholders. Perhaps the reason for better performance of the firms that have concentrated ownership structure is due to this factor that as you can see, the ownership has a significant effect on economic value added and refined economic value added and in a firm ownership structure when the major stockholders ownership rate increases, its performance will be improved.

\section{Research Limitations}

In the process of doing a scientific research, there are circumstances that are not in a way under the control of the researcher. Among the limitations of the present study some of them are as follows:

1) The present research like other descriptive studies has time and place limitations. This study time period consists 6 years from 1388 to 1393 and its location is Tehran Stock Exchange. So It cannot be generalized to other times and statistical populations accurately.

2) Another limitation of this study is to integrate a number of industries with each other. Since the number of companies in some industries such as wood products, printing and publishing were limited or after exerting the research requirements a lot of existing firms in some of the industries were removed so the number of firms in this study are limited.

3) Possible impact of differences in accounting methods (such as depreciation calculation method) on the items contained in the financial statements of companies may affect the results of the study and an adjustment has not been made in this regard.

4) Due to the limitations of the statistical population, to generalize the results of this research to other companies must be done with consideration of limitations.

5) Accounting Researches are often considered as after event researches, so there is not the possibility of being present during the variables occurrences although it can be said that this possibility is not exist in any of the researches even in Experimental science researches.

6) The political, economic, cultural and psychological conditions of Tehran Stock Exchange and the awareness level of people participating in the capital market and supply and demand, the volume of trade and economic prosperity or recession which affected the market also have some influences on the present research variables.

\section{Research Recommendations}

The present study, based on its findings and a review of other research literatures and information resources in this regard, present the following recommendations to the firms managers, Tehran Stock Exchange and investors:

1) In the present study, Tehran Stock Exchange listed companies are reviewed, therefore, it is recommended that in future studies the OTC companies also be evaluated.

2) to test the hypotheses of this study for longer periods of time, as well as separate industry groups in the Tehran Stock Exchange.

3) To examine the relationship between ownership structure (concentration and composition) using management accounting techniques and methods such as Balanced Scorecard, Activity Based Costing, quality management and ... in companies.

4) To review the relationship between ownership structure (concentration and composition) by exploring investment horizon (short-term and long-term) for investors.

5) In this study, the relationship between economic value added (EVA), refined economic value added (REVA), and ownership structure have been reviewed. This comparison can be generalized to other indicators such as return on assets, return on investment and etc.

6) To review the effect of some cases as company's life cycle, information asymmetry, the liquidity of stocks and ownership structure on the performance of companies listed on the Tehran Stock Exchange using economic value added (EVA), and refined economic value added (REVA), performance indicators. 
7) By considering the unobserved effects in the firm panel data model, and with a qualitative and field research approach, we can track the discovery of features and components not recognized in the final model of the study to add new dimensions of ownership structure to the research literature.

\section{References}

Ahmadpour, A., \& Ahmadi, A. (1387). The use of qualitative characteristics of information in assessing the quality of corporate profits. Accounting and Auditing Investigations, (52), 3.

Brown, L., \& Caylor, M. (n. d.). Corporate governance and firm operating performance. Working Paper, Georgia State University.

Bushee, B. J. (1998). The Influence of Institutional Investors on Myopic R\&D Investment Behavior. Accounting Review, 73(July), 305-334.

Chen, X., Harford, J., \& Li, K. (2007). Monitoring: Which institutions matter? Journal of Financial Economics, 86, 279-305. http://dx.doi.org/10.1016/j.jfineco.2006.09.005

Dittmar, A., \& Mahrt-Smith, J. (n. d.). Corporate governance and the value of cash holdings. Journal of Financial Economics.

Gedajlovic, E., \& Shapiro, D. (n. d.). Ownership structure and firm profitability in Japan. Academy of Management Journal.

Hassas, Y., Yahya, M., \& Eskandar, H. (1387). The relationship between institutional investors and corporate value. Accounting and Auditing Investigations, (52), 107-122.

Jensen, M. C. (1993). The Modern Industrial Revulation, Exit and the Failyre of the Internal Control Systems. Journal of Finance, 831-880. http://dx.doi.org/10.1111/j.1540-6261.1993.tb04022.x

Jensen, M. C., \& Meckling, W. (1976). Theory of the firm: Managerial behavior, agency costs, and ownership structure. Journal of Financial Economics, 3, 305-60. http://dx.doi.org/10.1016/0304-405X(76)90026-X

Joh, S. (2003). Corporate governance and firm profitability: Evidence from Korea before the economic crisis. Journal of Financial Economics, 68(2), 287-322. http://dx.doi.org/10.1016/s0304-405x(03)00068-0

Justin, T. W., Heibatollah, S., \& Haiyan, Z. (n. d.). Corporate Governance and Operating Performance of Chinese Listed Firms. Retrieved from http://www.ssrn.com

Kapopoulos, P., \& Lazaretou, S. (2007). Corporate Ownership Structure and Firm Performance: Evidence from Greek Firms. Corporate Governance: An International Review, 15(2), 144-158. http://dx.doi.org/10.1111/j.1467-8683.2007.00551.x

Maug, E. (1998). Large shareholders as monitors: Is there a trade-off between liquidity and control? Journal of Finance, 53, 65-98. http://dx.doi.org/10.1111/0022-1082.35053

Mohammad, K. P., \& HassanKarimi, V. K. (1393). The relationship between board structure,firm ownership and voluntary disclosure. Accounting Empirical Research, (4), 167-187.

Mueller, E., \& Spitz, A. (n. d.). Managerial Ownership and Company Performance in German Small and Medium-Sized Private Enterprises. German Economic Review.

Namazi, M., \& Kermani, E. (1387). The impact of ownership structure on the performance of companies listed on the Tehran Stock Exchange. Survey of Accounting and Auditing, (53), 83-100.

Niu, F. F. (2005). Corporate governance and the quality of accounting earnings: A Canadian perspective. International Journal of Managerial Finance, 2(4), 302-327 http://dx.doi.org/10.1108/17439130610705508

Noravesh, I., \& Ebrahimi, K. (1384). A review of the relationship between shareholders composition and information asymmetry and accounting standards of performance. Review of Accounting and Auditing, (42), 97-124.

Parrino, R., Sias, R. W., \& Starks, L. T. (2003). Voting with their feet: Institutional ownership changes around forced CEO turnover. Journal of Financial Economics, $68,46$. http://dx.doi.org/10.1016/S0304-405X(02)00247-7

Qla, M. R., \& Mehdi, G. A. (1393). An analysis of the relationship between corporate governance and economic value added in the Tehran Stock Exchange. Journal of Management Accounting Research, VII(21), 59-70.

Shleifer, A., \& Vishny, R. W. (1997). A survey of corporate governance. Journal of Finance, 52, 737-83. http://dx.doi.org/10.1111/j.1540-6261.1997.tb04820.x 
Talebi, M., \& Mohammadjalili. (1381). Application of economic value added information in evaluating financial performance of listed companies in Tehran Stock Exchange. PayameModiriat Journal, (3\&4).

Xu, X., \& Wang, Y. (1999). Ownership structure and corporate governance in Chinese stock companies. China Economic Review. http://dx.doi.org/10.1016/s1043-951x(99)00006-1

\section{Copyrights}

Copyright for this article is retained by the author(s), with first publication rights granted to the journal.

This is an open-access article distributed under the terms and conditions of the Creative Commons Attribution license (http://creativecommons.org/licenses/by/3.0/). 